\title{
GAMBARAN SITOLOGI SERVIKS PADA PEREMPUAN HIV DI PUSKESMAS JAKARTA
}

\author{
Arum Ambarsari \\ Program Pascasarjana Epidemiologi Komunitas, FKM UI, Depok, Indonesia \\ (email penulis korespondensi: arum.ambarsari@ui.ac.id )
}

Info Artikel: Diterima: 25 September $2019 \quad$ Revisi: 15 Oktober $2019 \quad$ Diterima: 03 November 2019

\begin{abstract}
ABSTRAK
Latar belakang: Skrining sitologi serviks belum menjadi hal yang rutin dilakukan di layanan rawat jalan HIV yang ada di fasilitas kesehatan primer di DKI Jakarta, padahal kondisi immunosupresi pada infeksi HIV diketahui dapat menyebabkan infeksi HPV yang persisten sehingga meningkatkan risiko mengalami lesi pra kanker dan kanker serviks pada wanita dengan HIV. Penelitian ini bertujuan untuk mengetahui gambaran sitologi serviks pada perempuan HIV yang mengakses layanan kesehatan di Puskesmas Kalideres Jakarta Barat.
\end{abstract}

Metode: Penelitian ini bersifat deskriptif dengan total sampling, menggunakan data sekunder berupa hasil papsmear pada 30 perempuan dengan HIV yang mengakses layanan di Puskesmas Kalideres yang mengikuti skrining kanker serviks pada bulan November 2017. Data karakteristik dan faktor risiko didapatkan dari rekam medis pasien dan catatan anamnesa saat menjalani skrining.

Hasil: Temuan papsmear abnormal adalah 16,7\% dengan $80 \%$ berupa peradangan dan $20 \%$ berupa lesi pra kanker serviks kategori ASCUS. Pada responden dengan keradangan faktor risiko yang terlihat adalah multipara (100\%), CD4 $<500 \mathrm{sel} / \mathrm{mm} 3$ (100\%), dan jumlah pasangan seksual lebih dari satu (50\%). Pada responden dengan hasil lesi pra kanker serviks memiliki faktor risiko hubungan seks di usia $<16$ tahun, multiparitas, jumlah pasangan seksual lebih dari 1 , dan jumlah CD4 $<500$ $\mathrm{sel} / \mathrm{mm}^{3}$.

Kesimpulan: Prevalensi abnormalitas hapusan sitology serviks pada perempuan yang mengakses layanan di Puskesmas Kalideres cukup tinggi yaitu sebanyak 16,7\% dengan prevalensi untuk lesi pra kanker serviks berupa ASCUS sebesar 3,3\%. Proporsi dari faktor risiko pada kasus adalah multiparitas (100\%), jumlah pasangan seksual lebih dari satu (60\%) dan kadar CD4 dibawah 500 $\mathrm{sel} / \mathrm{mm} 3(100 \%)$.

Kata kunci: HIV, Sitologi serviks, Wanita

\section{ABSTRACT}

Background: Cervical cytology screening has not become routine in HIV outpatient services at public health center in Jakarta, even though immunosuppression in HIV infection is known to cause persistent HPV infection, thereby increasing the risk of developing pre-cancerous lesions and cervical cancer in women with HIV. This study aimed to determine the description of cervical cytology in HIV women accessing health services at the Kalideres Public Health Center in West Jakarta.

Methods: This research was descriptive with total sampling, using secondary data in the form of pap smear results on 30 women with HIV who accessed services at the Kalideres Health Center who attended cervical cancer screening in November 2017. Characteristic data and risk factors were obtained from the patient's medical records and history records. while undergoing screening.

Results: The abnormal pap smear findings were $16.7 \%$ with $80 \%$ in the form of inflammation and $20 \%$ in the form of ASCUS cervical pre-cancerous lesions. Respondents with visible risk factors were multiparous (100\%), CD4 <500 cells / mm3 (100\%), and more than one sexual partner (50\%). Respondents with cervical pre-cancerous lesions had risk factors for sex at age <16 years, multiparity, number of sexual partners more than 1, and CD4 count $<500$ cells $/ \mathrm{mm}^{3}$.

Conclusion: The prevalence of cervical cytology abdominal abnormalities in women accessing services at the Kalideres Public Health Center was quite high with the prevalence for ASCUS cervical lesions in the form of ASCUS. Therefore, need to active screening by the staff of public health center. Keywords: HIV, cervical cytology, women 


\section{PENDAHULUAN}

Di Indonesia, kematian akibat kanker serviks menempati urutan kedua setelah kanker payudara. Berdasarkan laporan tahunan WHO tahun 2014, terdapat sekitar 21 ribu kasus baru kanker serviks dengan kematian sebanyak 9 ribu kasus (WHO, 2014). ${ }^{1}$ Infeksi persisten oleh Human Papilloma Virus (HPV) tipe risiko tinggi onkogenik merupakan penyebab kanker serviks pada $99,5 \%$ kasus. $^{2}$

Kondisi immunosuppresi pada infeksi HIV diketahui dapat meningkatkan kemungkinan infeksi HPV yang persisten pada perempuan yang terpapar, sehingga meningkatkan risiko mengalami lesi pra kanker dan kanker serviks. Infeksi HPV pada perempuan yang terinfeksi HIV juga lebih cenderung mengalami progresivitas menjadi invasif.$^{3}$ Penelitian di Nigeria menyebutkan bahwa infeksi HPV

\section{METODE}

Penelitian ini merupakan penelitian deskriptif dan berlangsung selama NovemberDesember 2017. Seluruh pasien HIV perempuan yang memenuhi kriteria inklusi diikutkan dalam penelitian ini. Kriteria inklusi meliputi perempuan HIV berusia 18-50 tahun, tercatat di register SIHA Jakarta Barat tahun 2017, tidak pernah menjalani hysterectomy dan bersedia mengikuti penelitian. Pengambilan data melalui rekam medis dan data skrining papsmear perempuan HIV yang diselenggarakan oleh program PTM Puskesmas Kalideres pada bulan November 2017. Data yang diambil meliputi karakteristik umum (usia, pendidikan, pekerjaan, paritas, status pernikahan, status pengobatan), kadar CD4 saat awal dilakukan pemeriksaan, usia saat pertama kali berhubungan seksual, jumlah pasangan seksual, riwayat merokok dan infeksi menular seksual.

Sediaan sitologi diambil di poliklinik

HIV Puskesmas Kecamatan Kalideres oleh tenaga terlatih bersertifikat, kemudian dilakukan fiksasi dengan larutan formalin buffer $10 \%$ untuk selanjutnya dibawa ke laboratorium Kimia Farma. Sediaan diperiksa dan dinilai oleh dokter Spesialis Patologi Anatomi sesuai standard yang berlaku. Pemeriksaan Pap smear dilakukan di meningkat 1,5 hingga 3 kali dan persistensinya tinggi pada perempuan HIV dibandingkan yang tidak HIV. ${ }^{4}$ Penelitian yang dilakukan di Denpasar melaporkan bahwa angka kejadian lesi pra kanker serviks pada $48 \%$ perempuan dengan HIV. $^{5}$

Penelitian tentang karakteristik sitologi serviks pada perempuan dengan HIV masih minim di Indonesia. Di Puskesmas Kalideres sampai dengan Oktober 2017 terdapat 35 perempuan dengan HIV yang rutin mengakses layanan ART di Poli Sehati. Studi ini bertujuan untuk mendesripsikan karakteristik perempuan dengan HIV di Puskesmas Jakarta yang meliputi karakteristik umum, kadar CD4, umur saat pertama berhubungan seks dan jumlah pasangan seksual, serta gambaran sitologi serviksnya melalui pemeriksaan Pap Smear.

meja ginekologi dalam posisi litotomi dengan alat spatula ayre dan cytobrush. Pasien saat diperiksa tidak sedang haid, tidak berhubungan seksual dua hari sebelumnya, tidak menggunakan obat-obatan yang dimasukkan ke dalam vagina. Setiap sediaan diberikan nomor identitas dan pengambil sediaan maupun pemeriksa sediaan tidak mengetahui identitas maupun status subyek penelitian. Setelah sediaan tiba di Laboratorium, teknisi akan memberikan nomer identitas laboratorium dan memastikan apakah sediaan representative atau memenuhi standar kualitas untuk dianalisis oleh dokter ahli Patologi Anatomi untuk kemudian dilakukan proses diagnosis. Klasifikiasi histopatologik menggunakan system Bethesda tahun 2001 dengan pembagian: negative, ASCUS, LIS derajat rendah, LIS derajat tinggi dan karsinoma. Data kategori yang merupakan hasil penghitungan akan dideskripsikan dalam bentuk frekuensi dan prosentasi. Data kontinyu selain akan dideskripsikan dalam bentuk frekuensi juga dihitung nilai mean dan median. 


\section{HASIL}

Tabel 1. Karakteristik Subyek Penelitian $(n=30)$

\begin{tabular}{|c|c|c|}
\hline Karakteristik & Jumlah & $\begin{array}{c}\text { Persentase } \\
(\%)\end{array}$ \\
\hline \multicolumn{3}{|l|}{ Umur } \\
\hline 1. $<30$ & 6 & 20 \\
\hline 2. $30-40$ & 17 & 56,7 \\
\hline 3. $41-50$ & 4 & 13,3 \\
\hline 4. 50 & 3 & 10 \\
\hline \multicolumn{3}{|l|}{ Pendidikan } \\
\hline 1. SD & 2 & 6,7 \\
\hline 2. SMP & 7 & 23,3 \\
\hline 3. SMA & 18 & 60 \\
\hline 4. $S-1$ & 3 & 10 \\
\hline \multicolumn{3}{|l|}{ Status Pekerjaan } \\
\hline 1. Bekerja & 8 & 26,7 \\
\hline 2. Tidak Bekerja & 22 & 73,3 \\
\hline \multicolumn{3}{|l|}{ Status Pernikahan } \\
\hline 1. Menikah & 21 & 70 \\
\hline 2. Cerai (mati/hidup) & 8 & 26,7 \\
\hline 3. Belum menikah & 1 & 3,3 \\
\hline \multicolumn{3}{|l|}{ Paritas } \\
\hline 1. Belum hamil & 1 & 3,3 \\
\hline 2. 0 & 4 & 13,3 \\
\hline 3. $1-2$ & 16 & 53,3 \\
\hline 4. $>2$ & 9 & 30 \\
\hline \multicolumn{3}{|l|}{ ARV } \\
\hline 1. $\mathrm{Ya}$ & 30 & 100 \\
\hline 2. Tidak & 0 & 0 \\
\hline
\end{tabular}

Berdasarkan Tabel 1 dijelaskan bahwa keikutsertaan peserta pada penelitian ini sejumlah 30 orang dengan HIV/AIDS dari 35 orang yang masih aktif berobat di poliklinik Sehati Puskesmas Kalideres Jakarta Barat. Sebanyak 2 orang menolak berpartisipasi dengan alasan takut dengan tindakan papsmear dan 3 orang tidak dapat mengikuti karena harus bekerja. Dari table 1 karakteristik pasien yang mengikuti penelitian, diketahui sebagian besar peserta berusia antara 30-40 tahun sebanyak 17 orang, dengan rerata usia adalah 36,63 tahun. Termuda berusia 22 tahun sedangkan tertua adalah usia 65 tahun.

Pendidikan yang dijalani peserta penelitian $60 \%$ adalah SMA, diikuti oleh tingkat SMP $(23,3 \%)$, hanya 3 orang yang tamat S-1 dan 2 orang yang tamat SD. Lebih dari separuh peserta penelitian yakni 73,3\% adalah ibu rumah tangga, yang bekerja 8 orang $(26,7 \%)$, kebanyakan bekerja di sektor swasta, 1 orang memiliki usaha sendiri (wiraswasta).

Data tentang status menikah $70 \%$ peserta penelitian berstatus menikah, cerai sebanyak $26,7 \%$ dan yang belum menikah sebanyak 1 orang $(3,3 \%)$. Jumlah anak yang dimiliki oleh peserta penelitian adalah 1-2 anak sekitar 53,3\% dari keseluruhan peserta. Jumlah anak 0 dimaksudkan disini peserta tersebut sudah menikah namun belum mempunyai keturunan. Ada satu orang peserta yang belum menikah dan belum memiliki anak. Seluruh peserta penelitian (100\%) sudah mendapatkan ARV di Puskesmas Kalideres. 
Tabel 2. Hasil Analisis Faktor Risiko HIV (n=30)

\begin{tabular}{lrc}
\hline Faktor Risiko & Jumlah & $\begin{array}{c}\text { Persentase } \\
(\boldsymbol{\%})\end{array}$ \\
\hline Hubungan seksual pertama & 3 & 10 \\
1. $<16$ & 27 & 90 \\
2. 16 & & \\
Hitung CD4 & 8 & 26,7 \\
1. < 200 & 19 & 63,3 \\
2. 200-500 & 3 & 10 \\
3. 500 & & \\
Multipartner & 12 & 40 \\
1. Ya & 18 & 60 \\
2. Tidak & & \\
Merokok & 12 & 40 \\
1. Ya & 18 & 60 \\
2. Tidak & & \\
IMS Ya & 3 & 10 \\
1. Ya & 27 & 90 \\
2. Tidak & & \\
$\quad$ & &
\end{tabular}

Berdasarkan Tabel 2 dari 30 orang responden, hubungan seksual pertama dibawah usia 16 tahun dilakukan oleh 3 peserta penelitian, dengan rata-rata usia hubungan seksual pertama 21,33 tahun. Sebagian besar peserta penelitian mempunyai kadar CD4 kurang dari $500 \mathrm{sel} / \mathrm{mm} 3$ dimana 8 orang $(26,7 \%)$ kurang dari 200 $\mathrm{sel} / \mathrm{mm} 3$ dan antara $200-500 \mathrm{sel} / \mathrm{mm} 3$ sebanyak 19 orang $(63,3 \%)$. Hanya 3 orang yang memiliki kadar CD4 diatas $500 \mathrm{sel} / \mathrm{mm}^{3}$.
Dua belas responden menjalani kehidupan seksual multipartner (40\%) dibandingkan dengan yang tidak melakukan hal tersebut sebanyak 18 orang atau $60 \%$.

Perempuan dengan HIV yang merokok sebanyak 40\% (12 responden) sedangkan sisanya mengaku tidak pernah merokok (18 responden atau 60\%). Hanya sebanyak 3 orang responden yang tercatat pernah mengalami IMS (Infeksi Menular Seksual) pada rekam medis.

Tabel 3. Cara Penularan Infeksi HIV $(n=30)$

\begin{tabular}{lrc}
\hline Cara Penularan & Jumlah & \% \\
\hline & 7 & \\
1. Seksual, suami IDU & 16 & 23,3 \\
2. Seksual, suami multipartner & 6 & 53,3 \\
3. Multipartner & 1 & 20 \\
4. IDU & & 3,3 \\
\hline
\end{tabular}

Berdasarkan Tabel 3 Lebih dari separuh responden mendapatkan infeksi HIV karena tertular pasangan yang multipartner $(53,3 \%)$, menyusul urutan kedua tertular pasangan yang merupakan pengguna putau (Injecting Drug
User) sebanyak 7 orang (23,3\%). Risiko penularan dari peserta sendiri sebagian besar adalah karena hubungan seksual multipartner (20\%) dan satu orang merupakan pengguna putau (IDU). 
Tabel 4. Distribusi Kelainan Serviks (n=30)

\begin{tabular}{lrc}
\hline Klasifikasi & Jumlah & $\begin{array}{c}\text { Persentase } \\
(\boldsymbol{\%})\end{array}$ \\
\hline 1. Normal & 25 & 83,4 \\
2. Sel Peradangan & 4 & 13,3 \\
3. ASCUS & 1 & 3,3 \\
\end{tabular}

Berdasarkan Tabel 4 dari 30 sampel tes Pap, seluruhnya dapat dilakukan pembacaan. Kelainan serviks yang diperiksa menggunakan sistem pelaporan Bethesda. Dua puluh lima peserta didapatkan hasil normal atau $83,4 \%$. Dan 4 responden ditemukan sel-sel radang, sedangkan

\section{PEMBAHASAN}

Pada penelitian ini, didapatkan data karakteristik sosiodemografi dimana sebagian besar peserta berumur 30-40 tahun dengan umur termuda 22 tahun dan tertua 65 tahun. Perempuan umu 30-40 tahun termasuk dalam kelompok usia reproduksi, dimana seseorang masih produktif untuk kehidupan, bekerja dan menghasilkan keturunan. Demikian pula kelompok umur ini secara seksual masih aktif. Hal ini sejalan dengan cara penularan HIV yang kebanyakan karena kontak seksual dengan suami yang sudah terinfeksi HIV lebih dulu. ${ }^{6}$

Pendidikan terbanyak adalah SMA dan mayoritas responden tidak bekerja (Ibu rumah tangga). Temuan ini cukup menarik karena kelompok ini pada umumnya memiliki risiko yang rendah untuk mendapatkan infeksi HIV. Imunitas yang rendah merupakan salah satu faktor risiko seseorang untuk mendapatkan infeksi HPV. Virus HPV saat ini diketahui sebagai penyebab terjadinya kanker serviks. Perempuan yang terinfeksi HIV akan mengalami infeksi HPV yang lebih berisiko menjadi keganasan atau infeksi persisten. Data yang dapat menjelaskan hal diatas adalah cara penularan infeksi HIV pada perempuan tersebut sebagian besar karena kontak seksual dengan suami yang sudah terinfeksi terlebih dahulu. Hal ini konsisten dengan data di Kementrian Kesehatan Republik Indonesia tahun 2016 bahwa prosentase penularan lewat hubungan seksual sebesar $66 \%{ }^{6}$

Sebagian besar suami dari peserta penelitian berperilaku seksual multipartner diikuti dengan pengguna narkotika suntik. Hal ini
1 orang responden memiliki hasil abnormal kategori ASCUS (Atypical Squamous Cells of Undetermined Significance). Total hasil papsmear abnormal dijumpai pada 5 peserta penelitian $(16,7 \%)$.

sesuai dengan data bahwa trend penularan lewat narkotika suntik memang semakin menurun, digantikan penularan infeksi HIV melalui transmisi seksual. ${ }^{6,7}$ Kontak seksual dini, dibawah usia 16 tahun rentan terhadap infeksi HPV karena serviks belum matang. Sel-sel serviks lebih mudah terinfeksi oleh bakteri dan virus pada perempuan muda daripada perempuan berumur seperti infeksi klamidia, gonorrhea dan HPV. Selain itu serviks yang belum matang dapat bertransformasi menjadi sel pra kanker dan selanjutnya berpotensi menjadi ganas. ${ }^{8,9}$

Terdapat 3 orang peserta yang melakukan hubungan seksual pertama di umur kurang dari 16 tahun. Angka yang didapatkan dari penelitian oleh Wright dkk di New York jauh lebih tinggi yaitu 48\%. ${ }^{10}$ Hal ini bisa jadi disebabkan oleh karena pertanyaan ini dianggap tabu oleh kultur timur sehingga jawaban responden cenderung menutupi hal yang sebenarnya.

Paritas juga ditengarai menjadi salah satu faktor risiko terjadinya kanker serviks. ${ }^{7,8,10}$ Pada penelitian ini, rata - rata responden yang memiliki anak lebih dari 1 , dimana rerata jumlah anak adalah 2, dengan jumlah anak terbanyak adalah 7. Pada penelitian ini 4 orang responden mengalami keradangan pada sel-sel serviksnya dan disarankan untuk dilakukan tes ulang 3 bulan kemudian. Berikut karakteristik responden yang mengalami keradangan.

Responden diketahui saat ini merupakan ibu rumah tangga, namun saat remaja responden merupakan wanita penghibur di sebuah panti 
pijat yang sekaligus menjajakan seks. Responden didiagnosis HIV di Puskesmas Kalideres pada tahun 2014 saat dilakukan skrining tes HIV pada ibu hamil dan responden menjalani program PPIA (Pencegahan Penularan HIV dari Ibu ke Anak) dengan hasil akhir anak non reaktif (tidak tertular HIV).

Hasil ini konsisten dengan berbagai penelitian yang dilakukan bahwa faktor-faktor risiko perempuan dengan HIV untuk mengalami keganasan berupa kadar CD4 dibawah 500 $\mathrm{sel} / \mathrm{mm} 3 .^{12,13,14}$ selain faktor risiko umum lain yang memperkuat yaitu berupa usia muda saat

\section{KESIMPULAN}

Prevalensi abnormalitas hapusan sitology serviks pada perempuan yang mengakses layanan di Puskesmas Kalideres cukup tinggi. Faktor risiko yang terlihat berperan adalah multiparitas, jumlah pasangan seksual lebih dari 1 (multipartner) dan kadar CD4 dibawah $500 \mathrm{sel} / \mathrm{mm} 3$. Umur saat pertama berhubungan seksual memberikan proporsi yang kecil pada total responden yang mengalami abnormalitas hapusan serviks (1 dari 5 responden), namun pada satu-satunya

\section{DAFTAR PUSTAKA}

1. WHO, 2014. Laporan Tahunan World Health Organization.

2. Andrijono,2010. Kanker Serviks, Edisi I, Divisi Onkologi, Dept Obstetri Ginekologi FKUI. Jakarta: Balai Penerbit FKUI

3. UNAIDS, 2016. HPV, HIV and Cervical cancer Leveraging synergies to save women's lives. UNAIDS 2016 Reference

4. Adebamowo, S. N., Olawande, O., Famooto, A., Dareng, E. O., Offiong, R., \& Adebamowo, C. A, 2017. Persistent LowRisk and High-Risk Human Papillomavirus Infections of the Uterine Cervix in HIVNegative and HIV-Positive Women. Frontiers in Public Health, 5. https://doi.org/10.3389/fpubh.2017.00178

5. Mariana, Mona, 2013. Kadar Cluster Differentiation 4 berhubungan dengan prevalensi lesi prakanker serviks pada wanita terinfeksi Human Immunodeficiency Virus (Tesis). Fakultas Kedokteran Universitas Udayana

6. Depkes RI, 2016. Infodatin AIDS 2016 berhubungan seksual,memiliki banyak pasangan seksual dan multipara. ${ }^{7,8}$

Semua responden yang mengalami keradangan pada sel serviksnya merupakan multipara dan memiliki kadar CD4 dibawah 500 $\mathrm{sel} / \mathrm{mm}^{3}$. Separuhnya (2 responden) memiliki pasangan seks lebih dari 1 , dan semuanya mengaku melakukan hubungan seksual pertama kali di usia > 16 tahun.

Sedangkan seorang responden dengan kelainan sitology serviks kategori ASCUS memiliki karakteristik berupa kurang dari 16 tahun (15 tahun) saat pertama kali berhubungan seks, multipartner seksual, multipara (7 anak) dengan kadar CD4 dibawah $500 \mathrm{sel} / \mathrm{mm} 3\left(328 \mathrm{sel} / \mathrm{mm}^{3}\right)$.

responden yang memiliki kelainan lesi pra kanker dengan kategori ASCUS memiliki faktor risiko ini. Keterbukaan responden dalam penelitian perlu di evaluasi lebih lanjut untuk pertanyaan yang bersifat tabu bagi norma masyarakat.

Oleh karena itu perlu adanya kebijakan untuk melakukan skrining sitologi serviks/pap smear bagi semua perempuan dengan infeksi HIV karena termasuk populasi berisiko tinggi.

7. Centers for Disease Control and Prevention, 2003. Revised classifications system for HIV infection and expanded surveillance case definition for AIDS among adolescents and adults. MMWR 41:1-19

8. Schorge, et al, 2008. Preinvasive Lesions of the Lower Genital Tract. In:Williams Gynecology $1^{\text {st }}$ ed. The McGraw-Hill, 2008 : 1224-1284

9. Al-Haaathi L and Landay A., 2001. HIV in the Female Genital Tract:Viral Shedding and Mucosal Immunity. Clinical Obstetric and Gynecology. June 2001;44:144-153.

10.Wright CT et al., 1994. Cervical Intraepithelial Neoplasia in Women Infected with Human Immunodeficiency Virus: Prevalence, Risk Factors, and Validity of Papanicolaou Smears. Obstetrics\&Gynaecology;84,1994:594

11.Chirenje, Z.M., 2005. HIV and cancer of the cervix. Clinical Obstetric and Gynaecology 19:269-276 
(JPP) Jurnal Kesehatan Poltekkes Palembang

Vol. 14, No. 2, Desember 2019, eISSN 2654-3427

12.Bower, M; Mazhar, D. \& Stebbing, J., 2006. Should Cervical Cancer be An Acquired Immunodeficiency Syndrome-Defining Cancer? Journal of clinical oncology 24:2417-2419

13.Parham et al, 2010. Implementation of cervical cancer prevention services for HIVinfected women in Zambia: measuring

program effectiveness. PubMed in https://www.ncbi.nlm.nih.gov/pmc/articles/P MC4237284

14. Massad et al, 2008. Squamous cervical lesions in women with human immunodeficiency virus: long-term follow-up. PubMed in http://www.ncbi.nlm.nih.gov/pubmed/185155 23 